\title{
Preliminary results about the efficacy of abamectin trunk injection against the walnut husk fly (Rhagoletis completa)
}

\author{
Máté Kiss ${ }^{1}\left[\right.$ · Imane Hachoumi ${ }^{2} \cdot$ Viktória Nagy $^{1} \cdot$ Márta Ladányi $^{3} \cdot$ Ádám Gutermuth $^{4} \cdot$ Árpád Szabó $^{1} \cdot$ Csilla Sörös $^{2}$
}

Received: 14 July 2020 / Accepted: 6 October 2020 / Published online: 7 November 2020

(c) The Author(s) 2020

\begin{abstract}
The walnut husk fly (Rhagoletis completa) is one of the main pests affecting common walnut in both Europe and America. This work examines the effects of abamectin on the development of walnut husk fly larvae by injecting the product Vertimec 1.8 EC (Syngenta) into the trunks of walnut trees in Hungary. In the case of properly injected trees, the infection rate was negligible and the abamectin content in the husk samples ranged between 1.54 and $3.00 \mathrm{ng} / \mathrm{g}$; controls show a very high (>90\%) infestation rate and an abamectin content under the detection limit. Abamectin residue measured in walnut kernel did not exceed the maximum residue limit; moreover, the active ingredient content was below the detection limit $(0.0003 \mathrm{mg} /$ $\mathrm{kg}$ ) in all the collected kernel samples. Our results confirm that trunk injection is a viable method for walnut pest control.
\end{abstract}

Keywords Abamectin $\cdot$ Juglans regia $\cdot$ Trunk injection $\cdot$ Walnut husk fly

\section{Introduction}

Walnut husk fly (Rhagoletis completa) is one of the main pests of common walnut and can cause significant economic damages not only in Hungary, but all over Europe (Van Steenwyk et al. 2010; Verheggen et al. 2017). This pest is native to the Midwestern USA and north-eastern Mexico. In Europe, it was first detected in Switzerland in 1988, from where it spread (Duso 1991). In Hungary, it was first detected in 2011 in Kôszeg (Voigt and Tóth 2013). The known hosts of $R$. completa are various Juglans species, on which the females lay eggs into the pericarp. Larvae hatching can last over 2 months, and feeding on walnut husk

Máté Kiss

kissmate0816@gmail.com

1 Department of Entomology, Faculty of Horticultural Science, Szent István University, Ménesi Street 44, Budapest 1118, Hungary

2 Department of Applied Chemistry, Faculty of Food Science, Szent István University, Villányi Street 29-43, Budapest 1118, Hungary

3 Department of Biometrics and Agricultural Informatics, Faculty of Horticultural Science, Szent István University, Villányi Street 29-43, Budapest 1118, Hungary

4 GreenUnit Kft., Pereszke Street 225/1, Budapest 1112, Hungary tissues causes brown-purple coloured spots (Guillén et al. 2011). Furthermore, the infected fruit facilitates the penetration of pathogens into the edible kernel as well as the shell surface itself (Duso and Lago 2006). These pathogens (fungi and bacteria) are responsible for considerable yield losses, as they shrink and rot the kernel, after which the infected walnut drops off the tree together with the husks. Damage can occur on 74-91\% of untreated orchards, with economic losses as high as 50\% (Duso and Lago 2006; Voigt and Tóth 2013).

Protection against the larvae is challenging because it is difficult to access them with insecticides and because adults fly for a long time (Nickel and Wong 1966). Protection should therefore be continuous from early July to midSeptember. Another problem is the typical large canopy of walnut trees, where treatment by foliar spray is impractical (Verheggen et al. 2017; Wise et al. 2014). Currently, control of $R$. completa is usually achieved by spraying method; however, trunk injection, a rediscovered plant protection technique, could be an alternative solution to combat this problem (Fettig et al. 2013; Van Steenwyk et al. 2010). With this technique, the pesticide is introduced directly into the vascular system (xylem) of the tree, which then reaches the feeding larvae (Ferracini and Alma 2008; Mota-Sanchez et al. 2009; Roach 1939). Injection techniques have several advantages over conventional spraying, such as (1) lower pesticide amounts are used, (2) the nutrient medium of 
larvae can be directly reached without any toxicokinetic difficulties, (3) closed vessels provide long lasting protection for the pesticide, (4) it is safe for non-target organisms (Acimovic 2014; Burkhard et al. 2015; Doccola and Wild 2012; Halley et al. 1993; Kobza et al. 2011).

\section{Materials and methods}

The experimental area was in Taksony, Hungary, where 7 walnut trees were chosen to be injected. The 8-year-old, walnut trees (Alsószentiváni 117) had previously not been treated with any kind of insecticide. The height of the trees is $4.5-5 \mathrm{~m}$, and the planting density is $10 \times 10 \mathrm{~m}$. Yellow sticky traps (Csalomon PALz) were used for the detection and monitoring of the presence of $R$. completa in the field. The first individual was detected on 15th of July, 2019. The trunk injection was performed on the 8th of July, 2019.

\section{Injection}

In the case of 5 trees, 10-20 $\mathrm{ml}$ of Vertimec $1.8 \mathrm{EC}$ (active ingredient: $18 \mathrm{mg} / \mathrm{ml}$ abamectin, Syngenta) was injected into 4 holes of the trunk (Table 1), besides the two control treatments (without injection + water control). A tree injector device was used for injection, which uses a drilled hole of the tree and has a pedal with two springs to provide adequate pressure for the injection of the liquid (Gutermuth 2017). This device can inject the liquid into the xylem with a maximum pressure of 12.6 bar. The injection time requirement is about $5 \mathrm{~min} /$ tree for one person. Walnut is a well injectable species, so the pressure was about 8 bar on average. $50 \mathrm{~mm}$ deep holes with a $3.5 \mathrm{~mm}$ diameter were drilled at the lower/ middle/upper third of the trunks of the trees with an electric screwdriver (Table 1). The point of the injection device was put into the holes, and the intended liquid was injected into the xylem system via the holes. The circumferences of the trees ranged between 28 and $33 \mathrm{~cm}$ at a trunk height of $130 \mathrm{~cm}$.

\section{Sample collection}

In two cases (4th, 5th trees), leaf samples were collected on the $5^{\text {th }}$ of September in order to check the distribution of the active ingredient in the canopy as a whole. To ensure sampling was representative, 25 composite leaves per tree were collected in three parallels from all parts of the canopy, following which their abamectin content was measured. Walnut fruit samples - all fruits were harvested from each tree-and their husks were collected from all 7 trees (Table 1) on the 19th of September, before their full maturity, which was possible because of the young age of the trees. This allowed us to avoid the natural falling of the walnut fruits and to collect the nuts and their husks together. First, an entomological investigation was performed on the fruits, after which the husks were separated from the nuts to prepare for a chemical investigation in three parallels. All samples were stored in a freezer at $-80{ }^{\circ} \mathrm{C}$ until chemical investigation.

\section{Entomological survey}

The infection rate was recorded in the case of the walnut fruit samples. Each denuded husk and its kernel was visually inspected or, in the cases when it was not enough to determinate whether it is infected or not, it was inspected with a stereo microscope (Zeiss Stemi 2000). The inspected fruits, regardless of size, were separated into two groups according to whether they were infected or not. After that, the husks and the nuts were stored at $-80{ }^{\circ} \mathrm{C}$ until the measurement of their active ingredient content. From the group of intact nuts, a certain amount was stored without freezing with the purpose of imitating traditional walnut processing and storing methods. In line with the methods, we dried and stored these samples by spreading them out at room temperature, carefully protecting them from mould and rancidity.

Table 1 Injection parameters, infestation rate caused by walnut husk fly and statistical analysis of infection and abamectin content

\begin{tabular}{llllllll}
\hline Tree (treatment) tags & $\begin{array}{l}\text { Total number } \\
\text { of holes }\end{array}$ & $\mathrm{ml} / \mathrm{hole}$ & $\mathrm{ml} / \mathrm{tree}^{\mathrm{a}}$ & $\begin{array}{l}\text { Location of drill } \\
\text { holes on the trunk }\end{array}$ & $\begin{array}{l}\text { Infection } \\
\text { rate (\%) }\end{array}$ & $\begin{array}{l}\text { Marascuilo-group } \\
\text { (infection rate) }\end{array}$ & $\begin{array}{l}\text { ANOVA- } \\
\text { group (a.i. } \\
\text { content) }\end{array}$ \\
\hline 1. (control) & 0 & 0 & 0 & - & 98 & $\mathrm{c}$ & $\mathrm{C}$ \\
2. (aqueous control) & 4 & 2.5 & 10 & Lower third & 92 & $\mathrm{c}$ & $\mathrm{C}$ \\
3. & 4 & 2.5 & 10 & Lower third & 10 & $\mathrm{a}$ & $\mathrm{A}$ \\
4. & 4 & 5 & 20 & Lower third & 1 & $\mathrm{a}$ & $\mathrm{AB}$ \\
5. & 4 & 2.5 & 10 & Lower third & 11 & $\mathrm{a}$ & $\mathrm{AB}$ \\
6. & 4 & 5 & 20 & Lower third & 4 & $\mathrm{a}$ & $\mathrm{A}$ \\
7. & 4 & 2.5 & 10 & Upper third & 31 & $\mathrm{~b}$ & $\mathrm{~B}$ \\
\hline
\end{tabular}

${ }^{\mathrm{a}} 10 \mathrm{ml}$ injection is equivalent to $180 \mathrm{mg}$ a.i. (abamectin) 


\section{Analysis of abamectin in samples}

The abamectin standard was obtained from Pestanal, Riedelde Haën, Germany, with a certified purity of $97.1 \%$. The EN 15662:2018 (QuEChERS) sample preparation procedure was used for extracting the active ingredient from the samples (European Standard-EN 2018). The chemicals used for residue measurement are described in Kmellár et al. 2010. In case of kernel samples, a defatting step was also integrated into the procedure, which included freezing out and dSPE cleaning with $\mathrm{C} 18$ sorbent. A HPLC-MS/MS instrument was used for determining abamectin content in plant materials, which was performed with an Agilent 1200 LC system coupled to an AbSciex 3200 Q TRAP mass spectrometer equipped with a Turbo V ESI Heated Ion Spray probe operate in positive MRM mode. Regarding the measurement parameters, the Single Residue Method of Abamectin published by the Community Reference Laboratories for Residues of Pesticides was applied (European Commission 2008). In order to achieve a lower quantification limit (QL), a $100 \mu \mathrm{L}$ injection volume was used with a flow rate of $0.3 \mathrm{ml} / \mathrm{min}$. To prevent signal loss, a $150{ }^{\circ} \mathrm{C}$ ion source temperature was used during the analyses. A matrix-matched calibration method was used to quantify the abamectin content of the samples. Expecting a small amount of abamectin content in the samples, method validation was performed for the detection limit (DL), quantification limit, linearity and matrix effect. The method validation was performed in accordance with document SANTE Guidelines (European Commission 2019). DL in the case of husk, leaves and kernel were $0.15,0.30$ and $0.30 \mathrm{ng} / \mathrm{g}$, while the QL values were $0.30,0.90$ and $0.90 \mathrm{ng} / \mathrm{g}$, respectively. The calibration curves were linear up to a concentration of $1000 \mathrm{ng} / \mathrm{ml}$, and the matrix effect calculated with the use of the Matuszewski equation was between 61 and 95\% (Matuszewski et al. 2003).

\section{Statistical analysis}

Statistical analysis was performed using the mean values of replicates. Differences in the abamectin concentrations of the husks were tested using one-way ANOVA. The Shapiro-Wilk test was applied to the normality of the residuals and homogeneity of variance was checked by applying Levene's test. The multiple pairwise comparison was performed with Tukey's HSD. Marascuilo's procedure was used (Marascuilo 1966) to compare the trees based on their infection rates. The statistical analysis was performed using IBM SPSS Statistics 25 and Excel 2016.

\section{Results}

\section{Infection}

The infection rate of the husks was very different. We detected a high infection rate in the case of $1^{\text {st }}$ and $2^{\text {nd }}$ trees, but in other cases, with the exception of the tree in the $7^{\text {th }}$ treatment, the number of infected husks was negligible. Based on the infection rate, we can say that the injected pesticide and the tested dose was appropriate for plant protection. In terms of infection, we can consider the 3rd, 4th, 5 th and 6th trees to be similar ('a' group), and they were infected to the smallest extent. Of these trees with their low infestation rates, the tree of the 7 th treatment is significantly different ('b' group) according to Marascuilo's procedure based on its infection rate $(P<0.05$, Table 1$)$. The trees with the most significant serious infections were the ones of the 1st and the 2nd control ('c' group). Although eggs were laid and hatched on the injected trees, most of them died in the first larval stage, which was visible on the green shell as some dry spots $1-2 \mathrm{~mm}$ in size and had no effects on the development of walnut. Note that the injected abamectin also showed notable efficiency against the mite species that usually occur in walnut cultivars.

\section{The concentration of the active ingredient in the samples}

Fifty-nine days after injection, leaf samples were collected from tree 3 and tree 4; the latter was injected in double doses. The abamectin content in the leaves of both trees was as high as 379 and $750 \mathrm{ng} / \mathrm{g}$, respectively. The concentration values correspond to the injected dose (Table 1). On the other hand, the distribution of the pesticide over the whole canopy was uneven. The RSD values were $96 \%$ and $42 \%$, respectively. Based on these results, we suspect that this concentration is sufficient for realizing abamectin's plant protection effects. Seventy-three days after injection, fruit samples (husk together with the walnut) were collected and investigated with respect to abamectin content (Fig. 1).

Much lower concentrations were measured in the husk as compared to the leaves. Significant differences were found among the active ingredient contents of the husks ( $F$ $(4 ; 10)=5.70, P<0.05)$. In the case of the treated trees, the abamectin content in the husk samples was between 0.29 and $3.00 \mathrm{ng} / \mathrm{g}$ (Fig. 1). The homogeneous group separation of the mean abamectin values according to Tukey's HSD and the one of the infection rates by Marascuilo's procedure coincide well. Abamectin was not detectable in the control samples.

Since walnuts have a high nutrition content, which makes them a valuable part of a healthy diet, we measured 
Fig. 1 Infection rate and abamectin concentration in the husk samples. DL detection limit $(0.15 \mathrm{ng} / \mathrm{g}$ in the case of husk). **Measured value $(0.29 \mathrm{ng} / \mathrm{g})$ is between DL and QL

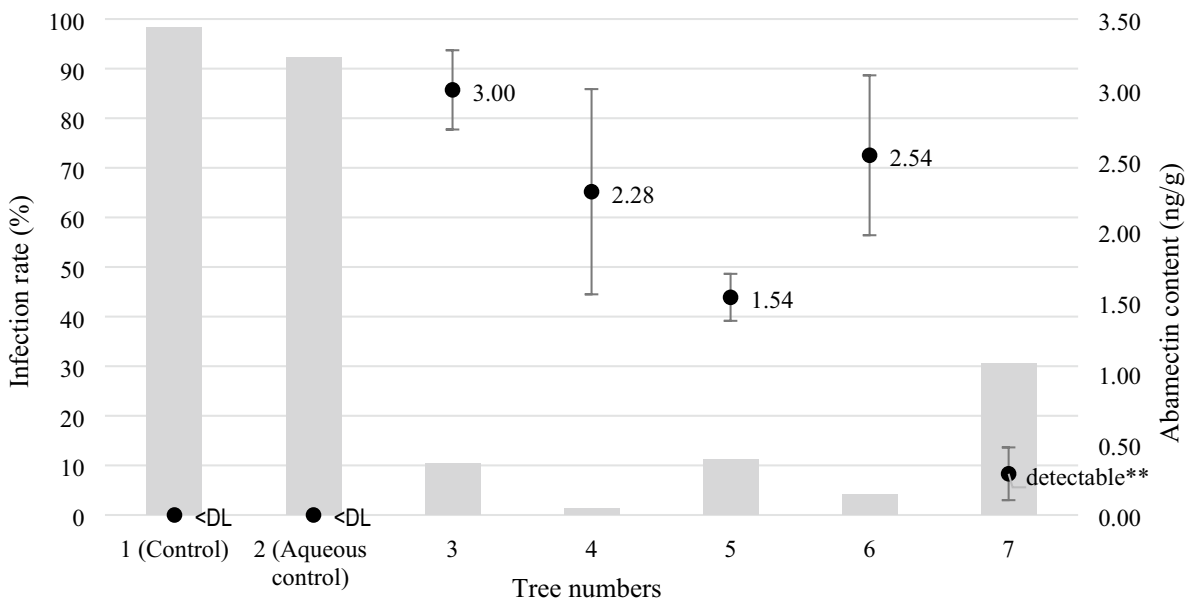

the abamectin residue content of the kernel as well. In all the collected kernel samples, the active ingredient content was below the detection limit $(0.0003 \mathrm{mg} / \mathrm{kg})$.

\section{Discussion}

The main goal of the present study was to provide a preliminary evaluation of the control of Rhagoletis completa in walnut cultivars through the trunk injection of a commercial abamectin formula. Although this plant protection technique is not commonly widespread, many of its benefits can be well utilized in fruit production, especially in cases when conventional spraying is not feasible (Schulte et al. 2006; Wise et al. 2014). The effectiveness of trunk injection treatment in walnut trees was evaluated based not only on the infection rate, but also on the active ingredient content of the plant parts. The latter provided direct data on the distribution and appearance of the active ingredient in the walnut husk, which is the target of the investigated pest. Moreover, the relation between the actual infection and the actual abamectin concentration of the husk was also tested. In the case of the control trees, intense infection (>90\%) was observed, due to the fact that the active ingredient could not be detected. These results show that the aqueous injection control does not contribute any plant protection effect, nor does the drilling of bores in the trunk induce any biochemical reaction that could result in a lower infection rate. As for the treated trees (trees 3-7), the infection rates were heterogeneous, but in every case they were much lower than in the controls. During our experiment, all five treatments successfully protected walnut trees against $R$. completa.

In our work, Vertimec 1,8 EC was used for injection. Although this product was not specifically developed for this purpose, it provided sufficient results. This outcome is contradictory to some previous observations, when the formulation with oil content was not useable for trunk injections.
Percival and Boyle (2005) examined certain fungicides with various active ingredients and formulations and found that only the water-soluble formulations were suitable for trunk injections while others, including emulsions, were less effective or ineffective. Unlike conventional spray application, the efficacy of injected pesticides is due to uptake and translocation from the injection site to target sites, which in turn depends on pesticide solubility, the health rate and the chemical composition of transport tissues, as well as on the tree species, the transpiration rate, the coal absorption coefficient and the metabolization/degradation of the active ingredient (Acimovic 2014; Doccola and Wild 2012; Ferracini and Alma 2008). This complexity can be the reason for the high pressure and significant time requirement that we experienced during the injection.

Our studies demonstrate that the height of the injection point also plays an important role in the success of the treatment. In the case of trees injected at the lower third of their trunks, the protection was more effective (the infection rate was below 11\%) and, accordingly, the active ingredient content was also found to be higher here compared to the tree injected in the upper region. In order to gain a homogeneous and adequate active ingredient level in the entirety of the canopy, a sufficiently low injection height has to be used as in this case the active ingredients have enough time to diffuse along the xylem sheaf before the transport reaches the branches (Fig. 1, trees 5 and 7).

The abamectin content in leaf samples was higher than in the husks. This is attributable to the fact that the injected compounds in the xylem move in the direction of water transport, which corresponds to the degree of evaporation of the different plant tissues (Doccola and Wild 2012; MotaSanchez et al. 2009).

The novelty of this work is the use of the trunk injection method in walnut pest control. We investigated the effects of the neurotoxin abamectin on the development of walnut husk fly larvae. By using both insecticidal and 
chemical investigations, we proved that the active ingredient was efficiently distributed in the canopy of walnut tree, and the injected dose was enough to provide an insecticidal effect. Abamectin residue measured in the kernel did not exceed the maximum residue limit $(0.02 \mathrm{mg} / \mathrm{kg})$ set by Regulation (EC) No 396/2005. This experiment provides insight into the trunk injection technology in walnut plant protection and confirms that trunk injection is a viable method for walnut pest control.

Our future plan is to investigate the effects of the present treatment next season, as residual activity is an already known phenomenon, and to try other forms and active agents (Holderness 1992; Percival and Boyle 2005).

We hope that our work will contribute to plant protection against invasive pests such as $R$. completa, which is an emerging problem threatening the cultivation of walnuts throughout Europe.

Acknowledgements This research was supported by the Human Resources Development Operational Program under Grant Number EFOP-3.4.3-16-2016-00012, by the European Union and co-financed by the European Social Fund (Grant Agreement No. EFOP3.6.3VEKOP-16-2017-00005), and by the Ministry for Innovation and Technology within the framework of the Higher Education Institutional Excellence Program (NKFIH-1159-6/2019) in the scope of plant breeding and plant protection research of Szent István University.

Authors' contribution All authors contributed to the study conception and design. Material preparation, data collection and analysis were performed by Máté Kiss, Imane Hachoumi, Ádám Gutermuth and Viktória Nagy. The first draft of the manuscript was written by Máté Kiss, and all authors commented on previous versions of the manuscript. All authors read and approved the final manuscript.

Funding Open access funding provided by Szent István University.

Availability of data and material Not applicable.

\section{Compliance with ethical standards}

Conflict of interest The authors declare that they have no known competing financial interests or personal relationships that could have appeared to influence the work reported in this paper.

Ethics approval The author warrants that the article is original, written by stated author/s, has not been published before, nor is it currently under consideration for publication elsewhere.

Consent to participate Informed consent was obtained from all individual participants included in the study.

Consent for publication Additional informed consent was obtained from all individual participants for whom identifying information is included in this article.

Code availability Not applicable.

Open Access This article is licensed under a Creative Commons Attribution 4.0 International License, which permits use, sharing, adaptation, distribution and reproduction in any medium or format, as long as you give appropriate credit to the original author(s) and the source, provide a link to the Creative Commons licence, and indicate if changes were made. The images or other third party material in this article are included in the article's Creative Commons licence, unless indicated otherwise in a credit line to the material. If material is not included in the article's Creative Commons licence and your intended use is not permitted by statutory regulation or exceeds the permitted use, you will need to obtain permission directly from the copyright holder. To view a copy of this licence, visit http://creativecommons.org/licenses/by/4.0/.

\section{References}

Acimovic SG (2014) Disease management in apples using trunk injection delivery of plant protective compounds. Michigan State University. Plant Pathology. https://doi.org/10.13140/2.1.2252.3841

Burkhard R, Binz H, Roux CA, Brunner M, Ruesch O, Wyss P (2015) Environmental fate of emamectin benzoate after tree micro injection of horse chestnut trees. Environ Toxicol Chem 34:297-302. https://doi.org/10.1002/etc. 2795

Community Reference Laboratory for Single Residue Methods. Analysis of Abamectin via QuEChERS and LC-MS/MS. Available from https://www.eurl-pesticides.eu/

Doccola JJ, Wild PM (2012) Tree injection as an alternative method of insecticide application. Insecticides-basic and other applications. InTech, Rijeka, Croatia 61-78

Duso C (1991) Sulla comparsa in Italia di un Tefritide neartico del noce: Rhagoletis completa Cresson (Diptera: Tephritidae). Boll Zool Agric Bachic 23:203-209

Duso C, Lago GD (2006) Life cycle, phenology and economic importance of the walnut husk fly Rhagoletis completa Cresson (Diptera: Tephritidae) in northern Italy. Annales de la Société entomologique de France 42:245-254. https://doi.org/10.1080/00379 271.2006.10700628

European Standard - EN 15662 (2018) Foods of plant origin-multimethod for the determination of pesticide residues using GC- and LC-based analysis following acetonitrile extraction/partitioning and clean-up by dispersive SPE-modular QuEChERS-method. Available from https://standards.cen.eu/. Accessed 7 July 2020

Ferracini C, Alma A (2008) How to preserve horse chestnut trees from Cameraria ohridella in the urban environment. Crop Protect 27:1251-1255. https://doi.org/10.1016/j.cropro.2008.03.009

Fettig CJ, Grosman DM, Munson AS (2013) Efficacy of abamectin and tebuconazole injections to protect lodgepole pine from mortality attributed to mountain pine beetle (Coleoptera: Curculionidae) attack and progression of blue stain fungi. J Entomol Sci 48:270-278

Guillén L, Aluja M, Rull J, Höhn H, Schwizer T, Samietz J (2011) Influence of walnut cultivar on infestation by Rhagoletis completa: behavioural and management implications. Entomol Exp Appl 140:207-217. https://doi.org/10.1111/j.1570-7458.2011.01157.x

Gutermuth ÁJ (2017) The injectability of deciduous trees. (Lombosfák injektálhatósága in Hungarian). Szent István University, Faculty of Horticultural Science

Halley BA, VandenHeuvel WJ, Wislocki PG (1993) Environmental effects of the usage of avermectins in livestock. Vet Parasitol 48:109-125. https://doi.org/10.1016/0304-4017(93)90149-H

Holderness M (1992) Comparison of metalaxyl/cuprous oxide sprays and potassium phosphonate as sprays and trunk injections for control of Phytophthora palmivora pod rot and canker of cocoa. Crop Protect 11:141-147. https://doi.org/10.1016/0261-2194(92)90097 $-\mathrm{O}$

Kmellár B, Abrankó L, Fodor P, Lehotay SJ (2010) Routine approach to qualitatively screening 300 pesticides and quantification of those frequently detected in fruit and vegetables using liquid 
chromatography tandem mass spectrometry (LC-MS/MS). Food Addit Contam 27:1415-1430. https://doi.org/10.1080/19440 049.2010 .490791

Kobza M, Juhasova G, Adamčíková K, Onrušková E (2011) Tree injection in the management of horse-chestnut leaf miner. Cameraria ohridella (Lepidoptera: Gracillariidae). Gesunde Pflanzen 62:139143. https://doi.org/10.1007/s10343-011-0236-z

Marascuilo LA (1966) Large-sample multiple comparisons. Psychol Bull 65:280-290. https://doi.org/10.1037/h0023189

Matuszewski BK, Constanzer ML, Chavez-Eng CM (2003) Strategies for the assessment of matrix effect in quantitative bioanalytical methods based on HPLC - MS/MS. Anal Chem 75:3019-3030. https://doi.org/10.1021/ac020361s

Mota-Sanchez D, Cregg BM, McCullough DG, Poland TM, Hollingworth RM (2009) Distribution of trunk-injected 14C-imidacloprid in ash trees and effects on emerald ash borer (Coleoptera: Buprestidae) adults. Crop Protect 28:655-661. https://doi. org/10.1016/j.cropro.2009.03.012

Nickel JL, Wong TT (1966) Control of the walnut husk fly, Rhagoletis completa Cresson, with systemic insecticides. J Econ Entomol 59:1079-1082. https://doi.org/10.1093/jee/59.5.1079

Percival GC, Boyle S (2005) Evaluation of microcapsule trunk injections for the control of apple scab and powdery mildew. Ann Appl Biol 147:119-127. https://doi.org/10.111 1/j.1744-7348.2005.00019.x

Regulation (EC) No 396/2005 of the European Parliament and of the Council of 23 February 2005 on maximum residue levels of pesticides in or on food and feed of plant and animal origin and amending Council Directive 91/414/EEC (Text with EEA relevance) Text with EEA relevance. Available from https://eur-lex.europ a.eu/legal-content/EN/TXT/?qid=1582307395827\&uri=CELEX :32005R0396. Accessed 7 July 2020
Roach WA (1939) Plant injection as a physiological method. Ann Bot 3:155-226

SANTE/12682/2019. European Commission D (2019) Guidance document on analytical quality control and method validation procedures for pesticides residues analysis in food and feed. Available from https://ec.europa.eu/. Accessed 7 July 2020

Schulte MJ, Martin K, Sauerborn J (2006) Effects of azadirachtin injection in litchi trees (Litchi chinensis Sonn.) on the litchi stink bug (Tessaratoma papillosa Drury) in northern Thailand. J Pest Sci 79:241. https://doi.org/10.1007/s10340-006-0142-9

Van Steenwyk RA, Zolbrod SK, Nomoto RM, Coates WW, Hasey JK, Elkins RB, Grant JA (2010) Walnut husk fly control with reduced risk insecticides. Acta Hortic 861:375-382. https://doi. org/10.17660/ActaHortic.2010.861.51

Verheggen F, Verhaeghe A, Giordanengo P, Tassus X, Escobar-Gutiérrez A (2017) Walnut husk fly, Rhagoletis completa (Diptera: Tephritidae), invades Europe: invasion potential and control strategies. Appl Entomol Zool 52:1-7. https://doi.org/10.1007/ s13355-016-0459-7

Voigt E, Tóth M (2013) Spread of the walnut husk fly in Hungary by spring of 2013. Növényvédelem 49:341-346

Wise JC, VanWoerkom AH, Acimovic SG, Sundin GW, Cregg BM, Vandervoort C (2014) Trunk injection: a discriminating delivering system for horticulture crop IPM. Entomol Ornithol Herpetol 3:1. https://doi.org/10.4172/2161-0983.1000126

Publisher's Note Springer Nature remains neutral with regard to jurisdictional claims in published maps and institutional affiliations. 